\title{
Electrochemical Determination of Trace Promethazine Hydrochloride by a Pretreated Glassy Carbon Electrode Modified with DNA
}

\author{
Zhou-Sheng Yang, ${ }^{\dagger}$ Jun ZhaO, Da-Peng Zhang, and Yun-Chun LiU \\ College of Chemistry and Materials Science, Anhui Key Laboratory of Functional Molecular Solids, \\ Anhui Normal University, Wuhu 241000, P. R. China
}

\begin{abstract}
A highly sensitive electrochemical biosensor for the detection of trace amounts of promethazine has been designed. Double stranded (ds)DNA molecules are immobilized onto a pretreated glassy carbon electrode (GCE(ox)) surface. The voltammetric behaviors of promethazine on DNA-modified electrode were explored by means of cyclic voltammetry (CV) and differential pulse voltammetry (DPV). The promethazine gave rise to a pair of well-defined peaks, which appeared at $E_{\mathrm{pc}}=52 \mathrm{mV}$ and $E_{\mathrm{pa}}=96 \mathrm{mV}(v s . \mathrm{Ag} / \mathrm{AgCl})$ in $0.10 \mathrm{M}$ acetate buffer (pH 5.0). The peak current was linearly enhanced with increasing the concentration of promethazine. The calibration was linear for promethazine over the range of $4.7 \times 10^{-10}$ to $9.3 \times 10^{-9} \mathrm{M}$ with a correlation coefficient of 0.999 . The limit of detection (LODs) was $3.0 \times 10^{-10} \mathrm{M}$ $(S / N=3)$. The modified electrode was applied to determine promethazine in human blood samples with satisfactory results.
\end{abstract}

(Received September 12, 2006; Accepted January 10, 2007; Published May 10, 2007)

Phenothiazines are a group of basic drugs that include a phenothiazine ring with different substituents attached at the 2and 10-position, which are used as anti-psychotics, neuroleptics and antihistamines. ${ }^{1}$ Several methods have been applied to detect phenothiazine derivatives, such as spectrophotometry, ${ }^{2}$ colorimetry, ${ }^{3}$ liquid chromatography (LC) ${ }^{4}$ and titrimetry. ${ }^{5}$ Promethazine hydrochloride, a prominent compound in the large group of phenothiazine derivatives, is widely used as a therapeutic agent for treating various mental and personality disorder. Daniela et al. ${ }^{6}$ have reported the determination of promethazine hydrochloride in a pharmaceutical preparation using a flow-injection spectroelectroanalytical method. Lara et $a l .{ }^{7}$ utilized a capillary zone electrophoresis (CZE) technique for the quantitative analysis of three kinds of phenothiazines. The detection limit for promethazine hydrochloride was obtained to be $3.3 \mu \mathrm{g} / \mathrm{mL}$; DPV and DC techniques were also applied to detect some phenothiazine drugs. ${ }^{8}$

The quantification of drugs or drug monitoring based on DNA-drug interactions has been reported. ${ }^{9-12}$ DNA is usually chosen as a surface-modification element because of its high sensitivity, and compatibility with modern micro-fabrication technologies; it is especially promising for rapid detection. ${ }^{13,14}$ Measurements of some trace phenothiazine drugs were performed with a DNA-modified carbon paste electrode (CPE) by using a potentiometric stripping analysis (PSA) method. DNA-modified CPE permits measurements at low concentration levels of some phenothiazines with an accumulation step. ${ }^{15}$ These previous studies suggested that a DNA-modified electrode might provide a very promising basis for determining trace promethazine.

In the present work, DNA-modified electrode was assembled by immobilizing dsDNA onto the surface of a pretreated glassy carbon electrode $(\mathrm{GCE}(\mathrm{ox}))$. A pair of well-defined reversible

$\doteqdot$ To whom correspondence should be addressed.

E-mail: yzhoushe@mail.ahnu.edu.cn redox peaks of promethazine was observed at low potential on the DNA/GCE(ox). The redox peak current was evaluated by using CV and DPV techniques. The signal was about 100-fold higher on DNA/GCE(ox) than that obtained on the DNA/GCE. By means of the redox peak currents of promethazine sensitively responding to the promethazine concentration, DNA/GCE(ox) could be applied to determine trace promethazine. The influence of a glassy carbon electrode pretreatment on the sensitivity of determining promethazine was considered. DNA/GCE(ox) was used to determine promethazine in healthy human serum with satisfactory results.

\section{Experimental}

Apparatus and reagents

Electrochemical measurements were performed with a CHI660A electrochemical analyzer (Shanghai Chenhua Apparatus Corporation, China). Glassy carbon electrodes (diameter $3 \mathrm{~mm}$ ) and DNA modified glassy carbon electrodes were used as the working electrode, respectively. A platinum auxiliary electrode and an $\mathrm{Ag} / \mathrm{AgCl}$ reference electrode were used for the measurements.

Calf thymus (CT) DNA (Cat. No. D1501) and promethazine hydrochloride (Cat. No. P4651) were purchased from Sigma. A DNA store solution was prepared in triple-distilled water, and was stored at $4^{\circ} \mathrm{C}$, and used for not more than 5 days. A promethazine stock solution was prepared by dissolving suitable amounts of promethazine hydrochloride in triple-distilled water (prior to oxygen being removed) and stored in a refrigerator at $4^{\circ} \mathrm{C}$. Standard solutions were then prepared from this stock solution by serial dilution, as required. The supporting electrolyte was $0.10 \mathrm{M}$ acetate buffer ( $\mathrm{pH} 5.0$ ). All of the solutions were prepared with triple-distilled water. High-purity nitrogen was used for a solution to remove oxygen, while keeping a nitrogen 


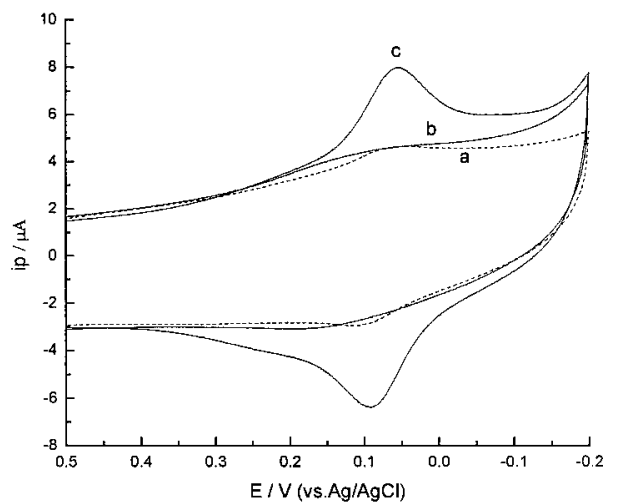

Fig. 1 Cyclic voltammograms for the DNA/GCE (a), GCE(ox) (b) and DNA/GCE(ox) (c) in a solution of $0.10 \mathrm{M}$ acetate buffer, $\mathrm{pH} 5.0$ containing $2.0 \times 10^{-9} \mathrm{M}$ promethazine. Temperature, $25^{\circ} \mathrm{C}$; scan rate, $50 \mathrm{mV} / \mathrm{s}$.

atmosphere over the solution during experiments. Measurements were carried out at room temperature.

\section{Procedure}

Polishing the glassy carbon electrode surfaces was performed with $0.25 \mu \mathrm{m} \mathrm{Al} \mathrm{O}_{3}$ and chammy, followed by rinsing with water. The electrode was washed with alcohol and double distilled water in an ultrasonic bath. The GCE was treated in a $0.10 \mathrm{M}$ phosphate buffer solution ( $\mathrm{pH}$ 5.0) by applying a potential of $+1.75 \mathrm{~V}$ for $300 \mathrm{~s}$ under constant stirring. Then, cyclic voltammetry was carried out in the same solution potential scan window from 0.30 to $1.25 \mathrm{~V}$ at a scan rate 50 $\mathrm{mV} / \mathrm{s}$, until a stable CV profile was obtained. ${ }^{16}$ This pretreated GCE was named GCE(ox).

DNA/GCE(ox) was prepared by placing a $25 \mu \mathrm{l}$ DNA solution $(1.0 \mathrm{mg} / \mathrm{ml})$ on the surface of $\mathrm{GCE}(\mathrm{ox})$ with a pipette, and leaving it to dry overnight. Then, the modified electrode was immersed into triple-distilled water for more than $15 \mathrm{~min}$ to remove any excess DNA. The electrode was thoroughly rinsed with triple-distilled water, and placed in a $0.10 \mathrm{M}$ acetate buffer solution ( $\mathrm{pH} 5.0$ ) at $4^{\circ} \mathrm{C}$ for use.

\section{Results and Discussion}

\section{Electrochemical properties of promethazine on a DNA-modified} electrode

Promethazine showed electrochemical activation on both bare GCE(ox) and DNA/GCE(ox). However, the promethazine exhibited a much larger signal on DNA/GCE(ox) under the same experimental condition. Figure 1 displays cyclic voltammograms of $2.0 \times 10^{-9} \mathrm{M}$ promethazine on bare $\operatorname{GCE}(\mathrm{ox})$ (b) and DNA/GCE(ox) (c). Promethazine on DNA/GCE(ox) gave rise to a pair of well-defined peaks, which appeared at $E_{\mathrm{pc}}=52 \mathrm{mV}$ and $E_{\mathrm{pa}}=96 \mathrm{mV}$ (vs. $\left.\mathrm{Ag} / \mathrm{AgCl}\right)$. This experimental result indicated that the promethazine has a stronger affinity to DNA/GCE(ox).

The surface pretreatment of a glassy carbon electrode is important to improve the electrochemical response of promethazine on the surface of an electrode. Promethazine only showed a weak reduction peak on bare GCE (curve not shown). However, it exhibited a pair of redox peaks, and the peak current was larger on bare GCE(ox) than that on bare GCE. This result indicated that promethazine yielded a better electrochemical response on bare $\operatorname{GCE}(\mathrm{ox})$ than that on bare

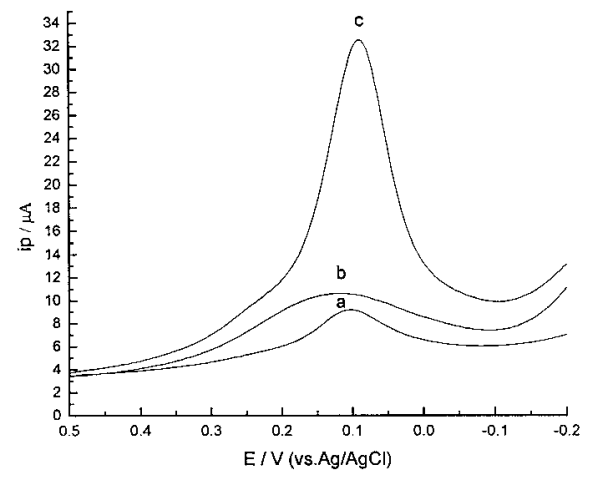

Fig. 2 Differential pulse voltammograms (DPV) for the DNA/GCE (a), GCE(ox) (b) and DNA/GCE(ox) (c) in the solution of $0.10 \mathrm{M}$ acetate buffer, $\mathrm{pH} 5.0$ containing $2.0 \times 10^{-9} \mathrm{M}$ promethazine. Pulse amplitude, $50 \mathrm{mV}$; pulse width, $50 \mathrm{~ms}$; pulse period, $0.2 \mathrm{~s}$; scan rate, $20 \mathrm{mV} / \mathrm{s}$.

GCE. When GCE and GCE(ox) were modified with DNA, respectively, promethazine showed an obviously different electrochemical behavior on two kinds of DNA modifiedelectrodes. Promethazine exhibited a much larger signal and better redox reversibility on the DNA/GCE(ox) (Fig. 1c) than that on the DNA/GCE (Fig. 1a). The above experimental results showed that a surface pretreatment of the glassy carbon electrode could improve the electrochemical response of promethazine. For a further verification of the importance of a pretreatment of GCE, a DPV measurement was carried out under the same experimental conditions. Figure 2 shows DPV curves of the promethazine on different electrodes. Promethazine exhibits a much larger signal on DNA/GCE(ox) (Fig. 2c) than that on the DNA/GCE (Fig. 2a) under the same experimental condition. These results further indicated that the redox activeness of the promethazine on DNA/GCE(ox) was improved.

The electrochemical response improvement of the promethazine on $\mathrm{GCE}(\mathrm{ox})$ was related to a change of the GCE(ox) surface. The activation of GCE(ox) involves the formation of a new phase. After the glassy carbon electrode was pretreated, some groups containing oxygen formed on the surface of the electrode. The formed groups containing oxygen made promethazine molecules contact the electrode closely by H-bind. Hence, the electron-transfer rate was improved on the $\mathrm{GCE}(\mathrm{ox})$. The electrochemical response of the promethazine on DNA/GCE(ox) could be enhanced.

\section{Dependence of the peak current on the DNA amount}

The magnitude of the redox peak current of the promethazine was influenced by the amount of DNA on the surface of $\mathrm{GCE}(\mathrm{ox})$. While controlling the concentration of promethazine to be $2.0 \times 10^{-9} \mathrm{M}$, the cathodic peak current of promethazine was plotted against the amount of DNA on the surface of GCE(ox). It was shown that the signal of promethazine gradually increased with the amount of DNA up to $0.28 \mathrm{mg}$ $\mathrm{cm}^{-2}$, above which it started to level off (shown in Fig. 3). Thus, $0.35 \mathrm{mg} \mathrm{cm}^{-2}(25 \mu \mathrm{l}$ DNA solution $(1.0 \mathrm{mg} / \mathrm{ml}))$ was chosen as the amount of DNA for all experiments.

Influence of $p H$ on $E_{p}$ and $i_{p}$

The solution $\mathrm{pH}$ value influenced the electrochemical properties of promethazine on DNA/GCE(ox). Figure 4 shows the dependence of the cathodic peak potential and the peak current of promethazine on the solution $\mathrm{pH}$ in the range from 


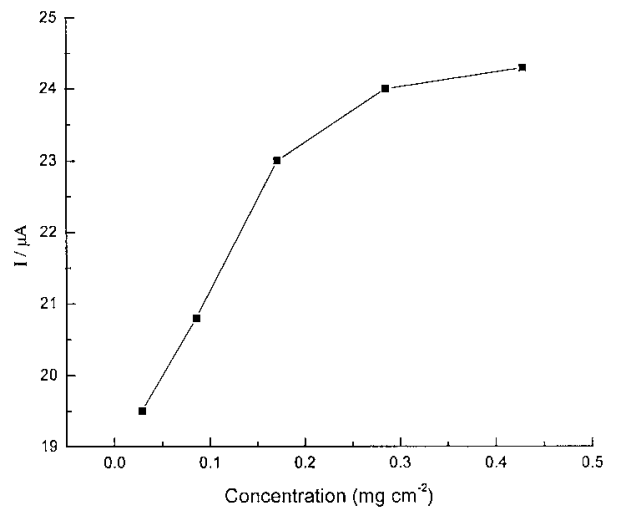

Fig. 3 Dependence of the cathodic peak current of promethazine on the amount of DNA on the surface of GCE(ox). DPV was performed in $0.1 \mathrm{M}$ acetate buffer $(\mathrm{pH} 5.0)$ containing $2.0 \times 10^{-9} \mathrm{M}$ promethazine. Other DPV conditions are the same as in Fig. 2.

3.0 to 7.0. The linear variety of the cathodic peak potential with the $\mathrm{pH}$ indicated that protons participated in the redox reaction of the promethazine on DNA/GCE(ox). The cathodic peak potential shifted with the $\mathrm{pH}$ as $E_{\mathrm{pc}}=0.312-0.061 \mathrm{pH}(r=$ 0.999) (Fig. 4a). The slope of $-61 \mathrm{mV}$ per $\mathrm{pH}$ unit suggests that two protons took part in the $2 \mathrm{e}^{-}$deoxidization process. Since the $\mathrm{pH}$ value of solution also influenced the shapes of the voltammograms, it is important to explore the effect of the $\mathrm{pH}$ on the electrochemical behavior. Figure $4 \mathrm{~b}$ shows the dependence of the cathodic peak current of promethazine on the solution $\mathrm{pH}$. The $\mathrm{pH}$ profiles shown in this figure could have resulted from that of protonation/deprotonation of the phosphate groups of the DNA modifier and promethazine in the solution. The electrostatic interaction between DNA and promethazine decreased due to protonation of the phosphate groups of DNA bellow 4.5. Above pH 5.0, the cathodic peak current of promethazine decreased with an increase of medium $\mathrm{pH}$, because deprontonation of promethazine also occurred at higher $\mathrm{pH}$; thus, promethazine could be easily oxidized. The maximum peak current was observed at around $\mathrm{pH}$ 5.0. Thus, $\mathrm{pH} 5.0$ was chosen as the optimum $\mathrm{pH}$. We also explored the influence of different buffer systems on the cathodic peak current of promethazine. Finally, the acetate buffer solution was selected as a suitable analytical medium.

\section{Detection of promethazine}

Because differential pulse voltammogram (DPV) is a technique with a better peak shape and higher sensitivity, ${ }^{17}$ DPV was employed for the determination of promethazine. Figure 5 shows DPV curves for various concentrations of promethazine. It can be obtained that the peak current increased with the promethazine concentration. In the range of $4.7 \times 10^{-10}-9.3 \times$ $10^{-9} \mathrm{M}$, the cathodic peak current is linearly proportional to the promethazine concentration. The equation of the resulting calibration plot (insert, Fig. 5) is $i_{\mathrm{p}}(\mu \mathrm{A})=4.3+10.1 c_{\text {promethazine }} \times 10^{9}$, and the correlation coefficient is 0.999. A detection limit of $3.0 \times 10^{-10} \mathrm{M}$ of promethazine can be estimated using $3 \sigma$ (where $\sigma$ is the standard deviation of a blank solution, $n=10$ ).

\section{Interferences}

The possible interference of several ions, such as $\mathrm{Na}^{+}, \mathrm{K}^{+}$, $\mathrm{Ca}^{2+}, \mathrm{Mg}^{2+}$ and $\mathrm{Cl}^{-}$, was examined. It was found that their influence on the electrochemical signal of promethazine was negligible for quantitative analysis at a 50:1 interference-to-

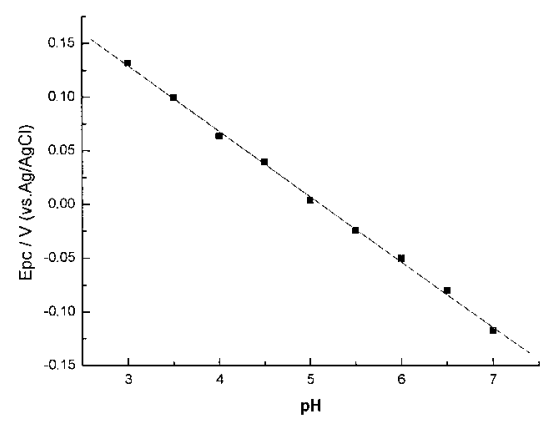

(a)

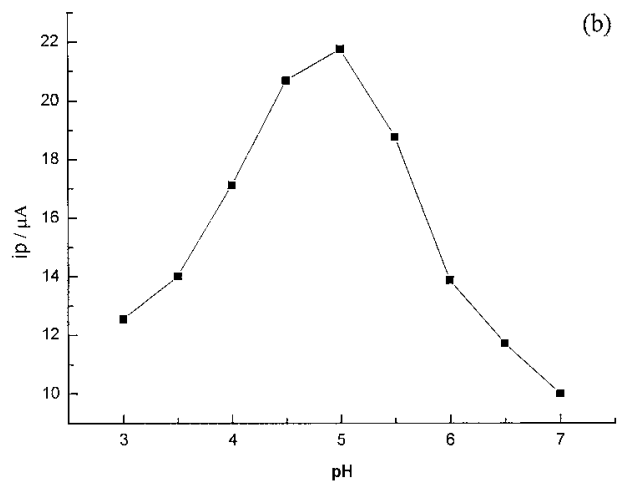

Fig. 4 Effect of the pH on the cathodic potential (a) and peak current (b) in a solution of $0.10 \mathrm{M}$ acetate buffer, $\mathrm{pH} 5.0$ containing $2.0 \times 10^{-9} \mathrm{M}$ promethazine. Other conditions are the same as in Fig. 2.

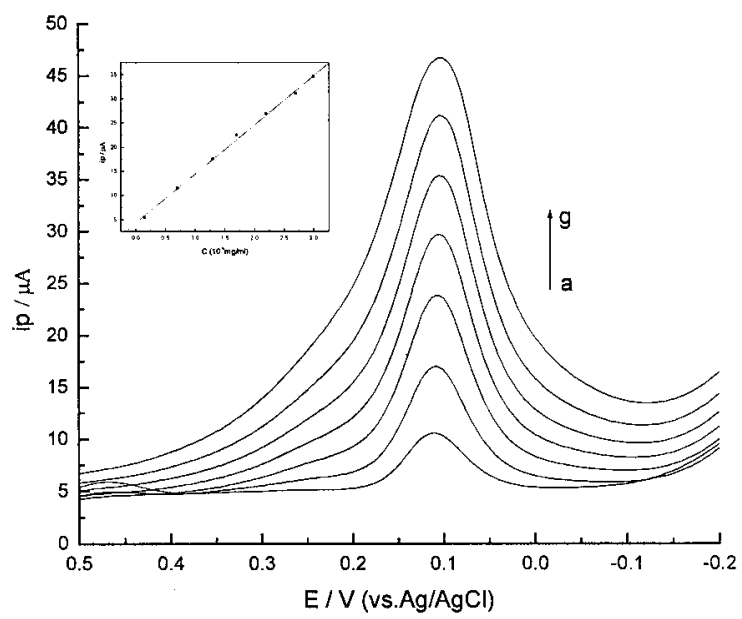

Fig. $5 \mathrm{DPV}$ for promethazine on DNA/GCE(ox) in $0.10 \mathrm{M}$ acetate buffer ( $\mathrm{pH}$ 5.0). The concentration of promethazine: (a) 0.47, (b) 2.2, (c) 4.1, (d) 5.3 , (e) 6.9, (f) 8.4, (g) $9.3\left(\times 10^{-9} \mathrm{M}\right)$. Other conditions are the same as in Fig. 2.

drug ratio under the experimental conditions. Furthermore, interferences from electrochemically active organic compounds, such as, ascorbic acid, starch, glucose and citric acid, were not observed at a ratio of 50:1 interference-to-drug.

\section{Determination of promethazine in human blood serum}

As a preliminary application in clinical studies, determinations of the promethazine concentration in human blood serum samples were performed by adding certain amounts of promethazine (in the range of $5.0 \times 10^{-10}-8.0 \times 10^{-9} \mathrm{M}$ ) into healthy human serum, which was diluted with $0.10 \mathrm{M}$ acetate buffer solutions ( $\mathrm{pH}$ 5.0). The recovery was calculated 


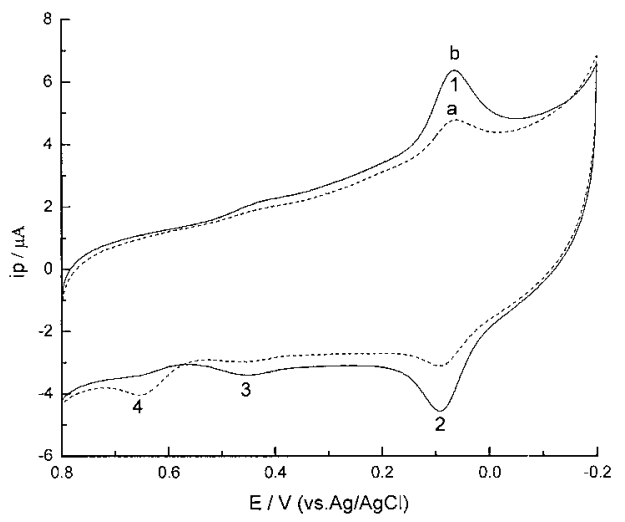

Fig. 6 Cyclic voltammograms of the promethazine on DNA/GCE(ox) in $0.10 \mathrm{M}$ acetate buffer, pH 5.0 containing $9.0 \times 10^{-9}$ $\mathrm{M}$ promethazine. The scan rate was $50 \mathrm{mV} / \mathrm{s}$. (a) $\mathrm{CV}$ recorded the first circles, (b) CV recorded after scanning 20 circles

according to the obtaining data. The results are shown in Table 1. The experiment results indicated that the proposed method for determining promethazine was not affected by the sample matrix. Therefore, it can be satisfactorily applied to determine promethazine in biological matrices.

\section{Redox mechanism of promethazine on DNA-GCE(ox)}

$\mathrm{Ni}$ et al..$^{18}$ reported that there were two oxidation peaks of the promethazine on GCE in $\mathrm{pH} 9.0$ Britton-Robinson buffers at 444 and $668 \mathrm{mV}$, respectively. No reduction peaks of the promethazine were observed. The author demonstrated that the promethazine is oxidized in steps involving two electrons and two protons. In our experiment, when $\mathrm{CV}$ was carried out from 0.80 to $-0.20 \mathrm{~V}$, the promethazine on DNA/GCE(ox) exhibited two oxidation peaks at 450 and $660 \mathrm{mV}$, respectively, and a pair of well-defined reversible redox peaks appearing at $E_{\mathrm{pc}}=52 \mathrm{mV}$ and $E_{\mathrm{pa}}=96 \mathrm{mV}$ during first scans (Fig. 6a). With the scan time increasing, the peak current at $E_{\mathrm{pa}}=660 \mathrm{mV}$ decreased, but the redox peak currents at $E_{\mathrm{pc}}=52 \mathrm{mV}$ and $E_{\mathrm{pa}}=96 \mathrm{mV}$ increased (Fig. 6b). Brett ${ }^{19}$ has reported that thiophene-S-oxides could be electrochemically reduced to the responding thiophene on the glassy carbon by forming an adduct of thiophene-S-oxides with dsDNA. According to a previous study and our experimental results, the possible redox mechanism of promethazine on the surface of DNA/GCE(ox) in an acidic medium was presented as follows. At the first scan, the promethazine diffused to the surface of the electrode, and was oxidized on DNA/GCE(ox) in steps. With the scan times increasing, the amount of promethazine accumulated by DNA gradually increased. Because the pretreated GCE could improve the redox activity of promethazine, the promethazine exhibited a reversible electrochemical redox process in which the promethazine probably underwent a two-electron transfer step.

\section{Conclusions}

In the present work, after GCE was pretreated, the DNA/GCE(ox) showed a good adsorption capability for promethazine through a strong interaction between DNA and promethazine. The promethazine gave rise to a pair of well-defined reversible peaks that appeared at a low potential on DNA/GCE(ox). A good linear relation of the peak current with the promethazine concentration was obtained. The promethazine had a high sensitivity on this
Table 1 Recovery and accuracy results for promethazine in human blood serum by the proposed method

\begin{tabular}{cccc}
\hline Added/nM & Found/nM & Recovery, $\%$ & Accuracy, ${ }^{\text {a }} \%$ \\
\hline 0.5 & 0.49 & 98.00 & -2 \\
0.5 & 0.52 & 104.00 & 4 \\
0.5 & 0.51 & 102.00 & 2 \\
2.0 & 2.02 & 101.00 & 1 \\
2.0 & 2.04 & 102.00 & 2 \\
2.0 & 1.98 & 99.00 & -1 \\
4.0 & 4.03 & 100.75 & 0.75 \\
4.0 & 3.96 & 99.00 & -1 \\
4.0 & 4.04 & 101.00 & 1 \\
8.0 & 8.04 & 100.50 & 0.5 \\
8.0 & 8.02 & 100.25 & 0.25 \\
8.0 & 7.98 & 99.75 & -0.25 \\
\hline
\end{tabular}

a. Accuracy $=[($ found - added $) /$ added $] \times 100$.

modified electrode. DNA/GCE(ox) could be satisfactorily applied to determine promethazine in biological matrices.

\section{Acknowledgements}

We thank the Natural Science Foundation of Anhui Provincial Education Department (No. 2006KJ116B) and (No. 2006KJ006TD) for financial support.

\section{References}

1. W. O. Foye, "Principios de Quimica Farmaceutica", 1999. Editorial Reverte, Barcelona, 222.

2. H. D. Revanasiddappa and P. G. Ramappa, Talanta, 1996, 43, 1291.

3. L. G. Hargis, J. A. Howell, and R. E. Sutton, Anal. Chem., 1996, 68, 169.

4. H. Hayen and U. Karst, Anal. Chem., 2003, 75, 4833.

5. R. K. Gilpin and L. A. Pachla, Anal. Chem., 1999, 71, 217.

6. D. Daniela and G. R. G. Ivano, Anal. Chim. Acta, 2003, 494, 215

7. F. J. Lara, A. M. García-Campaña, and F. Alés-Barrero, Anal. Chim. Acta, 2005, 535, 101.

8. S. A. John and R. Ramaraj, Langmuir, 1996, 12, 5689.

9. M. Aslanoglu, Anal. Sci., 2006, 22, 439.

10. C. Teijeiro, E. Red, and D. Marin, Electroanalysis, 2000, 12, 963.

11. H. Sun, L. Li, and X. Y. Chen, Anal. Sci., 2006, 22, 1145.

12. J. H. Xu, J. J. Zhu, Y. L. Zhu, K. Gu, and H. Y. Chen, Anal. Lett., 2001, 34, 503.

13. K. B. Wu, J. J. Fei, W. Bai, and S. S. Hu, Anal. Bioanal. Chem., 2003, 376, 205.

14. E. Palecek, M. Fojta, M. Tomschik, and J. Wang, Biosens. Bioelectron., 1998, 13, 621 .

15. J. Wang, G. Rivas, X. H. Cai, and H. Shiraishi, Anal. Chim. Acta, 1996, 332, 139.

16. H. S. Wang, H. X. Ju, and H. Y. Chen, Electroanalysis, 2001, 13, 1105.

17. R. Pongratz and K. G. Heumann, Anal. Chem., 1996, 68, 1262.

18. Y. Ni, L. Wang, and S. Kokot, Anal. Chim. Acta, 2001, 439, 159.

19. A. M. O. Brett, L. A. Silva, H. Fujii, and S. Mataka, J. Electroanal. Chem., 2003, 549, 91. 